Jurnal Mahasiswa BK An-Nur : Berbeda, Bermakna, Mulia

Volume 7 Nomor 3 Tahun 2021

Tersedia Online: https://ojs.uniska-bjm.ac.id/index.php/AN-NUR

p-ISSN. 2460-9722 | e-ISSN. 2622-8297

\title{
PENGEMBANGAN IDENTIFIKASI MULTIPLE INTELLIGENCE ( HOWARD GARDNER) BERBASIS APLIKASI ANDROID DALAM PENENTUAN PUTUSAN KARIR MAHASISWA DI YOGYAKARTA.
}

\author{
Ari Prasetyoaji $1^{1}$, Widi Fajar Widyatmoko ${ }^{2}$ \\ ${ }^{1,2}$ Universitas Teknologi Yogyakarta \\ E-mail: ariprasetyoaji@uty.ac.id / 08176378910 \\ E-mail: widifajar@uty.ac.id/0818260554
}

\begin{abstract}
ABSTRAK
Gardner menyatakan bahwa seorang anak manusia lahir ke dunia memiliki lebih dari satu potensi kecerdasan yang mungkin bisa berkembang, walaupun perkembangan tersebut berbeda dari satu orang dengan orang lain. Teknologi di era seperti ini menjadi sesuatu yang penting dalam menunjang aktivitas peningkatan kemampuan diri, sering berjalannya waktu pembelajaran online dan aplikasi yang bersifat mobile menjadi lebih pratkis digunakan untuk membantu pengoptimalan diri individu. Tujuan dari pengembangan aplikasi ini adalah untuk memudahkan mahasiswa di Yogyakarta dalam membuat putusan karir sehingga sesuai dengan kemampuan, kecerdasan yang ada pada dalam dirinya sendiri. Penelitian ini dikembangkan dengan menggunakan metode penelitian R\&D Borg \& Gall. Penelitian ini telah mengembangkan sebuah produk aplikasi untuk membantu mahasiswa dalam menentukan putusan karirnya melalui deteksi multiple intelligence yang dicetuskan oleh Howard Gardner, aplikasi ini terdiri atas 3 menu yaitu 1) multiple intelegence by howard gardner, 2) intelligence test ( howard gardner), dan 3) education about multiple intelgence.
\end{abstract}

Kata Kunci: Multiple intelligence, Howard Gardner, Putusan Karir, Aplikasi Android

\begin{abstract}
Technology in this era, especially during pandemic, has become something important in supporting selfimprovement activities. Online learning and mobile applications become more practical to use to help optimize individual self. This research has developed an application product to assist students in determining their career decisions through multiple intelligence detection initiated by Howard Gardner. The application that has been develop consists of 3 menus, namely 1) multiple intelligence by Howard Gardner, 2) intelligence test (Howard Gardner), and 3 ) education about multiple intelligences. Howard Gardner stated that every child has more than one potential intelligence that may be able to develop and the development of intelligence may differ from one person to another. The purpose of developing this application is to make it easier for students in Yogyakarta in making career decisions so that they are in accordance with the abilities, intelligence that exist within themselves. This research was developed using the Borg \& Gall R\&D research method.
\end{abstract}

Keywords: Multiple intelligence, Howard Gardner, Career Decision, Android Application

Dipublikasikan Oleh :

UPT Publikasi dan Pengelolaan Jurnal

Universitas Islam Kalimantan Muhammad Arsyad Al-Banjari Banjarmasin 
Ari Prasetyoaji ${ }^{1}$, Widi Fajar Widyatmoko ${ }^{2}$

Jurnal Mahasiswa BK An-Nur : Berbeda, Bermakna, Mulia

Volume 7 Nomor 3 Tahun 2021

Tersedia Online: https://ojs.uniska-bjm.ac.id/index.php/AN-NUR

p-ISSN. 2460-9722 | e-ISSN. 2622-8297

\section{PENDAHULUAN}

Setiap diri manusia memiliki intelligence yang beragam, hanya saja untuk mengoptimalkannya setiap individu memerlukan pemahaman yang lebih mendalam serta memahami kearah mana intelligence yang dimilikinya. Sukmadinata mengungkapkan bahwa setiap individu memiliki kecerdasan yang berbeda, individu memiliki beberapa kecerdasan, dan kecerdasan-kecerdasan itu bergabung menjadi satu kesatuan dan membentuk kemampuan pribadi yang cukup tinggi, Gardner menyatakan bahwa seorang anak manusia lahir ke dunia memiliki lebih dari satu potensi kecerdasan yang mungkin bisa berkembang, walaupun perkembangan tersebut berbeda dari satu orang dengan orang lain. Kecerdasan berkembang sesuai dengan lingkungan yang berpengaruh pada seorang diri individu [1]. Maka itu kecerdasanlah yang menjadikan perbedaan antara seorang dengan yang lainnya [8]. Kecerdasan menurut paradigma multiple intelligence Gardner [1] didefinisikan sebagai kemampuan yang mempunyai tiga komponen utama yaitu, kemampuan untuk menyelesaikan masalah yang terjadi dalam kehidupan nyata seharihari, kemampuan untuk menghasilkan persoalanpersoalan baru yang dihadapi untuk diselesaikan, dan kemampuan untuk menciptakan sesuatu atau menawarkan jasa yang akan menimbulkan penghargaan dalam budaya sesesorang.

Gardner menyusun daftar kecerdasan dalam buku "Frames of Mind yakni kecerdasan linguistic, kecerdasan logis-matematis, kecerdasan visualspasial, kecerdasan musical, kecerdasan gerak tubuh, kecerdasan interpersonal, kecerdasan intrapersonal, kecerdasan lingkungan, kecerdasan eksistensial. Teori multiple intelligence ini seolah menjawab kegelisahan pada dunia pendidikan yang dimana manusia hanya dipandangan kecerdasannya melalui dua jenis yaitu kecerdasan logika-matematika dan linguistic saja. Penerapan teori multiple intelligence menegaskan bahwa setiap individu yang hidup di bumi terlahir dengan sejumlah kecerdasan potensial dan diberkahi dengan keunikan unik untuk dikembangkan juga meningkatkan kemampuan dan mencapai tujuan dan sasaran kehidupan, terutama dalam proses pendidikan. Selain untuk menegaskan bahwa setiap individu memiliki keunikan tersendiri, multiple intelligence jika dipahai dapat membantu individu dalam menentukan arah karirnya, kecenderungan arah karirnya dapat dilihat lebih jelas ketika memahami ke arah mana kecerdaran diri sendiri.

Setiap individu yang sedang atau dalam masa kerjanya berhak untuk memiliki pengetahuan memahami multiple intelligence, hal tersebut berguna untuk mendukung pilihan karir kedepannya bagi para individu yang ingin mencari pekerjaan atau melanjutkan study, dan bagi individu yang sudah bekerja multiple intelligence dapat berguna untuk membantu meningkatkan individual skill sehingga dapat membantu dalam kenaikan jenjang karirnya.

Sebuah hasil penelitian yang dilakukan menyatakan bahwa $80 \%$ prestasi kerja ditentukan oleh soft skill (Karakter) dan hanya 20\% hard skill (pengetahuan dan keterampilan). Sekolah merupakan institusi yang paling strategis dalam pengembangan karakter yang sejatinya tertuang dalam rencana strategis sekolah (renstra). Namun, realitas lembaga pendidikan di Indonesia dalam proses pembelajaran hanya memberikan porsi $10 \%$ soft skill sedangkan hard skill sebesar 90\% [4]. Berdasarkan riset data yang dilakukan oleh Hootsuite serta platform media we are social yang bertajuk global digital report 2020, menunjukan hasil bahwa 338.2 Million individu sebagai mobile phone connection, dan 175.4 Million dari total populasi 272.1 adalah pengguna internet.

Teknologi di era seperti ini menjadi sesuatu yang penting dalam menunjang aktivitas peningkatan kemampuan diri, sering berjalannya waktu pembelajaran online dan aplikasi yang bersifat mobile menjadi lebih pratkis digunakan untuk membantu pengoptimalan diri individu. Seperti halnya yang sudah diungkapkan oleh Howard Gardner bahwanya dalam setiap diri individu terdapat kecerdasan yang apabila dioptimalkan akan membantu dalam meningkatkan karir ke arah yang lebih baik. Mengemas sebuah produk untuk membantu mahasiswa dalam membuat keputusan karir diera globalisasi seperti ini dirasa cukup membantu untuk membawa diri mahasiswa kearah yang lebih baik dalam pembuatan keputusan karir dan aplikasi yang dikemas dalam bentuk aplikasi andorid ini lebih efisien digunakan untuk pembelajaran online.

\section{METODE}

Penelitian ini menggunakan metode penelitian Research \& Development ( R \& D ) Borg \& Gall. Pengertian penelitian pengembangan menurut Borg \& Gall [11] adalah suatu proses yang dipakai untuk mengembangkan dan memvalidasi produk pendidikan. Penelitian ini mengikuti suatu langkahlangkah secara siklus. Langkah penelitian atau proses pengembangan ini terdiri atas kajian tentang temuan penelitian produk yang akan dikembangkan, mengembangkan produk berdasarkan temuan-temuan tersebut, melakukan uji coba lapangan sesuai dengan latar dimana product ersebut akan dipakai, dan melakukan revisi terhadap hasil uji coba lapangan. Penelitian dan pengembangan pendidikan itu sendiri dilakukan berdasarkan suatu model pengembangan berbasis industri, yang temuan-temuannya dipakai untuk mendesain produk dan prosedur, yang 
Ari Prasetyoaji ${ }^{1}$, Widi Fajar Widyatmoko ${ }^{2}$

Jurnal Mahasiswa BK An-Nur : Berbeda, Bermakna, Mulia

Volume 7 Nomor 3 Tahun 2021

Tersedia Online: https://ojs.uniska-bjm.ac.id/index.php/AN-NUR

p-ISSN. 2460-9722 | e-ISSN. 2622-8297

kemudian secara sistematis dilakukan uji lapangan, dievaluasi, disempurnakan untuk memenuhi kriteria keefektifan, kualitas, dan standar tertentu. Tahapan penelitian yang dirancang dan akan dipergunakan dalam penelitian ini ada sepuluh langkah yang harus dilakukan jika menggunakan model Borg \& Gall [11] untuk pengembangan suatu model atau produk. Kesepuluh langkah dimaksud masing-masing dijelaskan sebagai berikut:

a. Penelitian pendahuluan atau prasurvei

Tujuan pada tahap ini yaitu untuk mengumpulkan informasi mengenai model atau produk yang dikembangkan dan mengidentifikasi permasalahan yang mungkin dijumpai dalam pengembangan model atau produk. Langkah pada tahapan ini meliputi: kajian pustaka, pengamatan model yang telah ada, identifikasi masalah-masalah yang ada dalam pengembangan model atau produk, analisis kebutuhan, dan studi kelayakan.

b. Perencanaan penelitian

Perencanaan penelitian terdiri dari kegiatan perumusan tujuan penelitian, perkiraan dana, tenaga dan waktu, dan perumusan kualifikasi peneliti dan bentuk-bentuk partisipasinya dalam penelitian.

c. Pengembangan model atau produk awal

Kegiatan pada tahapan ini terdiri atas penentuan desain produk yang akan dikembangkan, penentuan sarana dan prasarana penelitian yang dibutuhkan selama proses penelitian dan pengembangan, penentuan tahap-tahap pelaksanaan uji desain di lapangan, penentuan deskripsi tugas pihak-pihak yang terlibat dalam penelitian.

d. Uji ahli dan pelaksanaan uji coba lapangan awal

Langkah ini merupakan uji model atau produk menurut ahli terkait dan disertai dengan uji lapangan awal secara terbatas, kegiatan yang dilakukan meliputi: Uji lapangan awal terhadap desain model atau produk, bersifat terbatas, baik substansi desain maupun pihak-pihak yang terlibat, uji lapangan awal dilakukan secara berulang-ulang sehingga diperoleh desain layak, baik substansi maupun metodologi

e. Revisi hasil uji lapangan awal atau terbatas

Langkah ini merupakan perbaikan model atau desain berdasarkan uji lapangan terbatas. Penyempurnaan produk awal dilakukan setelah dilakukan uji coba lapangan secara terbatas. Pada tahap penyempurnaan produk awal, lebih banyak dilakukan pendekatan kualitatif. Evaluasi yang dilakukan lebih pada evaluasi terhadap proses, sehingga perbaikan yang dilakukan bersifat perbaikan internal.

f. Pelaksanaan uji lapangan utama

Langkah ini merupakan uji model atau produk secara lebih luas meliputi: uji efektivitas desain model atau produk, biasanya menggunakan teknik eksperimen model pengulangan, hasil uji lapangan diperoleh desain yang efektif, baik dari sisi substansi maupun metodologi.

g. Revisi hasil uji lapangan utama

Langkah ini merupakan perbaikan kedua setelah dilakukan uji lapangan yang lebih luas dari uji lapangan yang pertama. Penyempurnaan produk dari hasil uji lapangan lebih luas ini lebih memantapkan produk yang dikembangkan, karena pada tahap uji coba lapangan sebelumnya dilaksanakan dengan adanya kelompok control. Desain yang digunakan adalah pre-test dan post-test. Selain perbaikan yang bersifat internal, penyempurnaan produk ini didasarkan pada evaluasi hasil sehingga pendekatan yang digunakan adalah pendekatan kuantitatif.

h. Uji kelayakan atau uji lapangan operasional

Langkah ini dilakukan dengan skala besar. Pada tahap ini dilakukan uji efektivitas dan adaptibilitas desain model atau produk yang melibatkan calon pemakai model atau produk.

i. Revisi final hasil uji kelayakan

Langkah ini akan lebih menyempurnakan produk yang dikembangkan. Penyempurna produk akhir perlu untuk lebih akuratnya produk yang dikembangkan. Pada tahap ini sudah didapatkan suatu model atau produk yang tingkat efektivitasnya dapat dipertanggung jawabkan. Hasil penyempurnaan akhir memiliki nilai "generalisasi" yang dapat diandalkan.

j. Diseminasi dan implementasi produk akhir

Pada tahahapan ini dibuat laporan hasil dari $\mathrm{R}$ \& D melalui forum-forum ilmiah, ataupun melalui media massa. Distribusi produk dilakukan setelah melalui control kualitas. .

\section{HASIL DAN PEMBAHASAN}

Hal yang akan terjadi ketika mahasiswa mampu membuat keputusan karir yang baik adalah tercapainya pengoptimalan karir yang baik dalam perkembangan karirnya. Kecerdasan yang dimiliki oleh individu dalam dirinnya jika dioptimalkan dengan baik maka bisa membantu pengoptimalan karir. Seperti halnya yang sudah diungkapkan oleh Howard Gardner bahwa seorang anak manusia lahir ke dunia memiliki lebih dari satu potensi kecerdasan yang mungkin bisa berkembang, walaupun perkembangan tersebut berbeda dari satu orang dengan orang lain. Kecerdasan berkembang sesuai dengan lingkungan yang berpengaruh pada seorang diri individu. Maka itu kecerdasanlah yang menjadikan perbedaan antara seorang dengan yang lainnya. Kecerdasan menurut paradigma multiple intelligence Gardner didefinisikan sebagai kemampuan yang mempunyai tiga komponen utama yaitu, kemampuan untuk menyelesaikan masalah yang 
Ari Prasetyoaji ${ }^{1}$, Widi Fajar Widyatmoko ${ }^{2}$

Jurnal Mahasiswa BK An-Nur : Berbeda, Bermakna, Mulia

Volume 7 Nomor 3 Tahun 2021

Tersedia Online: https://ojs.uniska-bjm.ac.id/index.php/AN-NUR

p-ISSN. 2460-9722 | e-ISSN. 2622-8297

terjadi dalam kehidupan nyata sehari-hari, kemampuan untuk menghasilkan persoalan-persoalan baru yang dihadapi untuk diselesaikan, dan kemampuan untuk menciptakan sesuatu atau menawarkan jasa yang akan menimbulkan penghargaan dalam budaya sesesorang.

Pengujian adalah proses mengeksekusi program secara intensif untuk menemukan kesalahan - kesalahan. Pengujian tidak hanya untuk mendapatkan program yang benar, namun juga memastikan bahwa program tersebut bebas dari kesalahan - kesalahan dalam berbagai kondisi. Menurut Pressman (2002: 215), SQA meliputi :(1) pendekatan manajemen kualitas; (2) teknologi rekayasa perangkat lunak yang efektif; (3) kajian teknik formal dalam penerapan seluruh proses perangkat lunak; (4) strategi pengujian deret bertingkat; (5) pengaturan dokumentasiperangkat lunak dan perubahan yang dibuat; (6) prosedur untuk menjaminkesesuaian dan standar pengembangan perangkat lunak; (7) mekanisme pengukuran dan pelaporan.

Dalam perkembangan di era globalisasi seperti ini media menjadi sesuatu yang sangat penting dan banyak diminati oleh pengguna smartphone, aplikasi yang mampu memberikan informasi dan membantu individu dalam pengoptimalan dirinya menjadi sebuah trobosan yang sangat menarik. Aplikasi android dalam penentuan putusan karir mahasiswa D. I. Yogyakarta ini terbagi atas 1) multiple intelegence by howard gardner, 2) intelligence test ( howard gardner), dan 3) education about multiple intelgence yang dapat membantu mahasiswa dalam menentukan keputusan karir kedepannya.

Untuk mengetahui sebuah kualiatas dari sebuah aplikasi dibutuhkan adanya penilaian, penilaian ini harus dilakukan oleh ahli yang berkompeten dibidangnya. Penilaian ahli ini bertujuan untuk menilai kelayakan dari sebuah media baik dari sisi visual media atapun isi materi didalamnya, harapannya dari penilian ini adalah terciptannya sebuah media yang benar-benar layak dan tepat sasaran berguna untuk kebutuhan pemilihan putusan karir. Penilaian dari media konteks visual media sendiri terdiri atas Panduan \& Informasi, Kinerja Program, SEPR. untuk penilaian dari materi meliputi Panduan \& Informasi, Konten/ Materi Multimedia dan Evaluasi.

Hasil dari pengembangan media aplikasi andorid dalam memambantu membuat keputusan karir mahasiswa melalui pemahaman kecerdasan howard gardner adalah terciptanya media yang identifikasi kecerdasan howard gardner yang terdiri atas 90 item meliputi 1) logical mathematical intelligence, 2) linguistic intelligence, 3) visual- spasial intelligence, 4) bodily-kinesthetic intelligence, 5) musical intelligence, 6) interpersonal intelligence, 7) intrapersonal intelligence, 8) naturalist intelligence, dan 9) existensialis intelligence. Aplikasi ini terdiri atas perpaduan audio video yang menunjang pemahaman dan referensi kecerdasan yang ada dalam diri individu.

\section{PENUTUP}

Dalam membuat putusan karir sering kali individu merasa kebingungan atas apa yang sesuai dengan dirinya sendiri dan menjadi kemampuan atas apa yang dimiliki oleh dirinya sendiri, Howard Gardner telah mencetuskan sebuah teori bahwasannya dalam diri individu memiliki keunikan dan memiliki intelligence yang beragam diantaranya adalah 1) logical mathematical intelligence, 2) linguistic intelligence, 3) visual-spasial intelligence, 4) bodilykinesthetic intelligence, 5) musical intelligence, 6) interpersonal intelligence, 7) intrapersonal intelligence, 8) naturalist intelligence, dan 9) existensialis intelligence. Kecerdasaran tersebut yang dimana jika dioptimalkan akan membantu individu dalam pengoptimalan karirnya sehingga bisa mencapai puncak karir yang diharapkannya. Penelitian ini telah mengembangkan sebuah produk aplikasi untuk membantu mahasiswa dalam menentukan putusan karirnya melalui deteksi multiple intelligence yang dicetuskan oleh Howard Gardner, aplikasi ini terdiri atas 3 menu yaitu 1) multiple intelegence by howard gardner, 2) intelligence test ( howard gardner), dan 3) education about multiple intelgence.

\section{REFERENSI}

Ali, Noor Rochmad. 2015. Analisis Konsep Howard Gardner Tentang Kecerdasan Majemuk (Multiple Intelegence) dan Implikasinya Terhadap Pembelajaran yang Sesuai dengan Perkembangan Anak di TK Alam Alfa Kids Pati Tahun Ajaran 2014/2015. Universitas Negeri Walisongo: Semarang.

Efendi, Muhammad Arifin. 2019. Pengembangan Aplikasi Informasi Jenis Profesi Berbasis Android Untuk Layanan Informasi Karir Pada Peserta Didik Sekolah Menengah Atas Negeri 6 Bandar Lampung. Universitas Lampung.

Gardner, Howard. 2011. Frames of Mind "The Theory of Multiple Intelligences. New York: Basic Books.

Masaong, Kadim. 2012. Pendidikan Karakter Berbasis Multiple Intelligence. Konaspi VII Universitas Negeri Yogyakarta 
Ari Prasetyoaji ${ }^{1}$, Widi Fajar Widyatmoko ${ }^{2}$

Jurnal Mahasiswa BK An-Nur : Berbeda, Bermakna, Mulia

Volume 7 Nomor 3 Tahun 2021

Tersedia Online: https://ojs.uniska-bjm.ac.id/index.php/AN-NUR p-ISSN. 2460-9722 | e-ISSN. 2622-8297

Mundiri, A (2016) Strategi Lembaga Pendidikan Islam dalam Membangun Branding Image. Pedagogik, 3(2)

Mundiri, A., \& Zahra, I. 2017. Implementasi Metode Stifin dalam Meningkatkan Kemampuan Menghafal Al-Quran di Rumah Quran Stifin Paiton Probolinggo. Journal of Islamic Education Studies 5(2), https://doi.org/10.15642/jpai.2017.5.2.201.223

Safaat. 2011. Android Pemrograman Aplikasi Mobile Smartphone dan Tablet PC Berbasis Android. Informatika: Bandung

Setyosari, Punaji. 2013. Metode Penelitian Pendidikan \& Pengembangan. Prenamedia Grup: Jakarta

Ulum, Nafi'atul. 2020. Konsep Kecerdasan Majemuk Perspektif Howard Gardner dan Penerapannya dalam Pembelajaran di Madrasah Ibtidaiyah. Universitas Islam Negeri Sunan Ampel Surabaya. 